Note

\section{Isolation of Biogenetically Correlated Four Alkaloids from the Cultures of Penicillium corymbiferum}

\author{
Sadahiro Oнмомо, Tsutomu ŌHASHI \\ and Matazo ABE* \\ Institute of Applied Biochemistry, \\ The University of Tsukuba, Sakura, \\ Ibaraki 305. Japan \\ *Faculty of Agriculture, Tamagawa University, \\ Machida, Tokyo 194, Japan
}

Received December 3, 1979

In the previous paper, ${ }^{1-3)}$ we isolated four new indole alkaloids, roquefortine $\mathrm{A}, \mathrm{B}, \mathrm{C}$ and $\mathrm{D}$ together with festuclavine from the cultures of Penicillium roqueforti. Recently, we isolated a Penicillium strain having the ability to produce at least four alkaloids I, II, III and IV in the course of screening fungi for their alkaloid productivity. By close investigation on morphological characteristics, this strain was identified as Penicillium corymbiferum. In this paper, we report the isolation and identification of these four alkaloids.

Alkaloid I and II were isolated in crystalline form from the culture filtrates ( $c a .5 .4$ liters) in the yields of 45 and $30 \mathrm{mg}$, respectively, by the routine procedure using silica gel column chromatography. Alkaloid III was obtained at first as crude powder containing alkaloid IV from the said culture filtrates by the same technique. This powder was purified repeatedly by the use of silica gel column chromatography, giving pure crystals of III and $\mathbf{~ V}$ in the yields of 240 and $210 \mathrm{mg}$, respectively.

I and II were identical with roquefortine $\mathrm{C}^{1,2)}$ and $\mathrm{D},{ }^{3)}$ respectively, not only in the physico- and spectro-chemical properties but also in the mixed melting point with authentic samples.

III and IV were identical with cyclopenol ${ }^{4.5)}$ and cyclopenine, ${ }^{4,5}$ respectively, which were isolated from the cultures of Penicillium cyclopium, not only in the physicoand spectro-chemical properties but also in the mixed melting point with authentic samples.

Judging from the assumed biosynthetic route ${ }^{6)}$ of roquefortine $\mathrm{C}$ and $\mathrm{D}$, and from that ${ }^{7}$ of cyclopenol and cyclopenine, these four alkaloids seem to be biosynthesized in used Penicillium in the correlation as shown in Fig. 1 .

In further screening tests, it was found that roquefortine $\mathrm{C}$ was produced also by Penicillium expansum IFO 5854 and Penicillium urtica IFO 7010 together or independently with roquefortine $\mathrm{D}$.
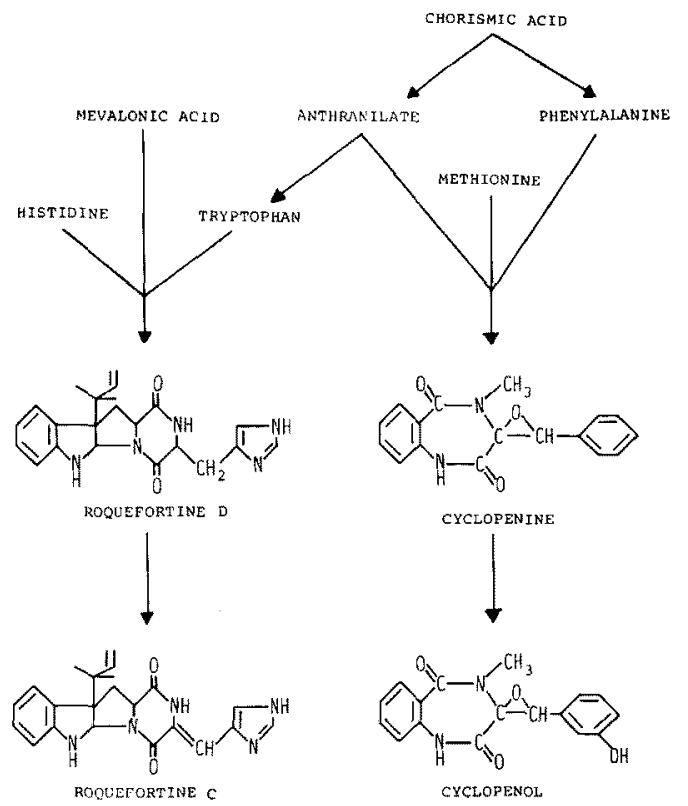

FIG. 1. Possible Biosynthetic Relationships among Roquefortine C, Roquefortine D, Cyclopenol and Cyclopenine in Penicillium corymbiferum.

\section{EXPERIMENTAL}

Fungus and cultivation. A strain of Penicillium corymbiferum, isolated from the soil in Tokyo, was cultivated at $30^{\circ} \mathrm{C}$ for 15 days in 1 liter Roux flasks containing each $200 \mathrm{ml}$ of a modification of MGS-medium. ${ }^{8)}$ The medium was composed of mannitol $3 \%$, glucose $1 \%$, succinic acid $1 \%, \mathrm{KH}_{2} \mathrm{PO}_{4} 0.1 \%, \mathrm{MgSO}_{4} \cdot 7 \mathrm{H}_{2} \mathrm{O} 0.03 \%, \mathrm{NH}_{4} \mathrm{OH}$ to $\mathrm{pH}$ 5.6 and tap water.

Isolation of $\mathbf{I}$ (roquefortine $C$ ) and $\mathbf{I I}$ (roquefortine $D$ ) The alkaloids were extracted from the culture filtrates ( $c a$. 5.4 liters) of $P$. corymbiferum with ethyl acetate after made alkali with aqueous ammonia ( $\mathrm{pH} c a$. 10). The alkaloidal solution was concentrated to dryness and the residue was passed through a column $(\phi 2.0 \times 80 \mathrm{~cm})$ containing $150 \mathrm{~g}$ of silica gel (Wako, Wakogel Q-23) suspended in ammoniacal chloroform.* The column was first eluted with $500 \mathrm{ml}$ of ammoniacal chloroform*1 containing $1 \%$ ethanol $(v / v)$, next eluted with $800 \mathrm{ml}$ of ammoniacal chloroform* containing 3\% ethanol $(\mathrm{v} / \mathrm{v})$ and last eluted with $800 \mathrm{~m}$ ] of ammoniacal chloroform* containing $5 \%$ ethanol $(\mathrm{v} / \mathrm{v})$ at a rate of $20 \mathrm{~g} /$ tube $/ 40 \mathrm{~min}$. I was contained in fractions No. $42 \sim 54$, III was in fractions No. $58 \sim 72$ together with IV, and II was in fractions No. 80 107.

The fractions No. $42 \sim 54$ were combined and evap-

* Mixture of 10 parts of chloroform and one part of chloroform saturated with conc. aqueous ammonia. 
orated to dryness under reduced pressure. The residue gave crystals of $\mathrm{I}$ from methanol in colorless needles $(45 \mathrm{mg})$ : $\operatorname{mp} 225 \sim 228^{\circ} \mathrm{C}$ (decomp.), $[\alpha]_{\mathrm{D}}^{15}-763^{\circ}$ (c=0.5, pyr.), molecular formula $\mathrm{C}_{22} \mathrm{H}_{23} \mathrm{~N}_{5} \mathrm{O}_{2}$ [Found: $\mathrm{C}, 67.08 ; \mathrm{H}, 5.82$; $\left.\mathrm{N}, 17.01 ; \mathrm{m} / \mathrm{e}, 389\left(\mathrm{M}^{+}\right)\right]$.

On the other hand, the fractions No. $80 \sim 107$ were combined and evaporated to dryness. The residue gave crystals of II from acetonitrile in colorless prisms $(30 \mathrm{mg})$ : $\mathrm{mp} 154^{\circ} \mathrm{C},[\alpha]_{\mathrm{D}}^{15}-371^{\circ}(c=0.25$, pyr.), molecular formula $\mathrm{C}_{22} \mathrm{H}_{25} \mathrm{~N}_{5} \mathrm{O}_{2}$ [Found: $\mathrm{C}, 67.74 ; \mathrm{H}, 7.12 ; \mathrm{N}, 17.03 ; \mathrm{m} / \mathrm{e}, 391$ $\left.\left(\mathrm{M}^{+}\right)\right]$.

Isolation of III (cyclopenol) and IV (cyclopenine). The fractions No. $58 \sim 72$ of column chromatography mentioned before were combined and evaporated to dryness under reduced pressure. The residue was next passed through a column $(\phi 1.8 \times 60 \mathrm{~cm})$ containing $100 \mathrm{~g}$ of silica gel (Wako, Wakogel Q-23) suspended in chloroform. The column was in turn eluted with (i) $500 \mathrm{ml}$ of chloroform containing $2 \%$ methanol $(\mathrm{v} / \mathrm{v})$, (ii) $300 \mathrm{ml}$ of chloroform containing $5 \%$ methanol $(\mathrm{v} / \mathrm{v})$ and (iii) $500 \mathrm{ml}$ of chloroform containing $10 \%$ methanol $(\mathrm{v} / \mathrm{v})$ at a rate of $15 \mathrm{~g} / \mathrm{tube} / 30 \mathrm{~min}$. III was contained in fractions No. $43 \sim 60$ and IV was in fractions No. $20 \sim 40$.

These fractions No. $43 \sim 60$ were combined and evaporated to dryness under reduced pressure. The residue gave crystals of III from methanol in colorless needles (240 mg): $m p 217^{\circ} \mathrm{C}$ (decomp.), $[\alpha]_{\mathrm{D}}^{20}-250^{\circ}(c=0.32$, pyr.), $[\alpha]_{5461}^{20}-310^{\circ}(c=1.0, \mathrm{MeOH})$, molecular formula $\mathrm{C}_{17} \mathrm{H}_{14} \mathrm{~N}_{2} \mathrm{O}_{4}$ [Found: C, 66.10; H, 4.52; N, 9.11; m/e, 310 $\left(\mathrm{M}^{+}\right)$. Calcd. for $\mathrm{C}_{17} \mathrm{H}_{14} \mathrm{~N}_{2} \mathrm{O}_{4}: \mathrm{C}, 65.80 ; \mathrm{H}, 4.55 ; \mathrm{N}, 9.03$; MW, 310.28]. IR $v_{\max }^{\mathrm{KBr}} \mathrm{cm}^{-1}: 3340,3200,1690,1610$. MS $m / e: 310\left(\mathrm{M}^{+}\right), 253,189,161,146,119$. NMR $\delta_{\text {TMS }}^{\text {DMso. }} 3.10$ $(3 \mathrm{H}, \mathrm{s}), 4.22(1 \mathrm{H}, \mathrm{s}), 6.7 \sim 7.7(8 \mathrm{H}, \mathrm{m}), 9.45$ (1H, br. s), $10.60(1 \mathrm{H}, \mathrm{s})$.

On the other hand, the fractions No, $20 \sim 40$ were combined and evaporated to dryness. The residue gave crystals of IV from methanol in colorless needles $(210 \mathrm{mg})$ : mp $182^{\circ} \mathrm{C}$ (decomp.), $[\alpha]_{D}^{20}-231^{\circ}\left(c=0.40\right.$, pyr.), $[\alpha]_{5461}^{20}$ $-291^{\circ}(c=1.0, \mathrm{MeOH})$, molecular formula $\mathrm{C}_{17} \mathrm{H}_{14} \mathrm{~N}_{2} \mathrm{O}_{3}$ [Found: $\mathrm{C}, 69.48 ; \mathrm{H}, 5.05 ; \mathrm{N}, 8.82 ; m / e, 294\left(\mathrm{M}^{+}\right)$. Calcd. for $\left.\mathrm{C}_{17} \mathrm{H}_{14} \mathrm{~N}_{2} \mathrm{O}_{3}: \mathrm{C}, 69.37 ; \mathrm{H}, 4.80 ; \mathrm{N}, 9.52 ; \mathrm{MW}, 294.28\right]$. IR $v_{\max }^{\mathrm{KBr}} \mathrm{cm}^{-1}: 3150,1705,1615 . \mathrm{MS} m / e ; 294\left(\mathrm{M}^{+}\right), 237$,

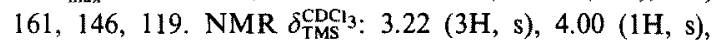
$6.5 \sim 7.6(9 \mathrm{H}, \mathrm{m}), 9.35(1 \mathrm{H}$, br. $\mathrm{s})$.

Acknowledgment. We wish to express our sincere thanks to Dr. M. Luckner, Professor of Martin-Luter University, for his kind supply of authentic samples of cyclopenol and cyclopenine. We also wish to express our sincere thanks to Dr. H. Inoue and Dr. T. Asao, professors of Tōhoku University, for their kind co-operation in elemental analysis and spectra measurements.

\section{REFERENCES}

1) S. Ohmomo, T. Sato, T. Utagawa and M. Abe, Agric Biol Chem., 39, 1333 (1975); idem, Nippon Nôgeikagaku Kaishi, 49, 615 (1975).

2) S. Ohmomo, T. Utagawa and M. Abe, Agric. Biol. Chem., 41, 2097 (1977).

3) S. Ohmomo, K. Oguma, T. Ōhashi and M. Abe, Agric. Biol. Chem., 42, 2387 (1978).

4) Y. S. Mohammed and M. Luckner, Tetrahedron Letters, 1963, 1953.

5) J. H. Birkinshaw, M. Luckner, Y. S. Mohammed, K. Mothes and C. E. Stickings, Biochem. J., 89, 196 (1963).

6) S. Ohmomo, T. Ōhashi and M. Abe, Agric. Biol. Chem., 43, 2035 (1979).

7) S. Voigt, S. E. Kousy, N. Schwells, L. Nover and M. Luckner, Phytochemistry, 17, 1705 (1978).

8) S. Ohmomo, K. Miyazaki, T. Ohashi and M. Abe, Agric. Biol. Chem., 41, 1707 (1977). 